NOTE

\title{
Evidence of horizontal transmission of the cancer-associated Steamer retrotransposon among ecological cohort bivalve species
}

\author{
Ashley N. Paynter ${ }^{1}$, Michael J. Metzger ${ }^{2}$, Jocelyn A. Sessa ${ }^{3}$, Mark E. Siddall ${ }^{1, *}$ \\ ${ }^{1}$ Sackler Institute of Comparative Genomics, American Museum of Natural History, New York, New York 10024, USA \\ ${ }^{2}$ Department of Biochemistry and Molecular Biophysics, Columbia University, New York, New York 10032, USA \\ ${ }^{3}$ Division of Paleontology, American Museum of Natural History, New York, New York 10024, USA
}

\begin{abstract}
Bivalve specimens from legacy frozen tissue collections, and others freshly obtained, were surveyed for the presence of the Steamer long terminal repeat (LTR)-retrotransposon associated with disseminated hemic neoplasia of the soft-shelled clam Mya areneria. Of 22 species investigated using primers for the pol region, only Atlantic M. arenaria, Atlantic and North Sea razor clams Ensis directus, and Baltic clams Macoma balthica from the North Sea were found to possess copies of Steamer in their genomes. Notably, close relatives like Mya truncata and Siliqua patula did not exhibit evidence of Steamer. Amplified Steamer sequences were uniformly identical in all $M$. areneria specimens, and were highly variable across specimens of $E$. directus. Variation in the latter included nucleotide polymorphisms among and within individuals as well as length variation in 2 specimens corresponding to the deletion of a predicted stable hairpin structure. Results implicate Atlantic razor clams as the proximal source for horizontal transmission of Steamer among ecologically similar yet markedly distantly related bivalves. The consequences of cross-species transmission of the Steamer retrotransposon are unknown, and the finding of Steamer in 3 bivalve species suggests that further spread is possible.
\end{abstract}

KEY WORDS: Disseminated neoplasia $\cdot$ Hemic neoplasia $\cdot$ Retrotransposon $\cdot$ Steamer $\cdot$ Bivalvia $\cdot$ Cancer Resale or republication not permitted without written consent of the publisher

\section{INTRODUCTION}

Disseminated, or hemic, neoplasias are leukemialike conditions that affect circulating hemocytes of a variety of bivalve mollusks (Carballal et al. 2015). Advanced stages of the disease, with tissue infiltration by neoplastic hemocytes, are fatal in most affected bivalves (Barber 2004, Metzger et al. 2015). Since first described in oysters from the eastern coast of the USA (Farley 1969), similar pathologies have been found globally in at least 23 bivalve species (Barber 2004, Carballal et al. 2015). Although both prevalence and mortality vary by species and by locality, particularly susceptible populations include northwest Atlantic soft-shelled clam Муа arenaria
(Barber 2004, Carballal et al. 2015), northeast Atlantic common cockle Cerastoderma edule (Barber 2004, Carballal et al. 2015), northeast Pacific bay mussel Mytilus trossulus (Barber 2004, Carballal et al. 2015), and several populations of Baltic clam Macoma balthica (Christensen et al. 1974, Pekkarinen 1993, Thiriot-Quiévreux \& Wolowicz 1996).

Whereas a variety of biotic and abiotic factors have been proposed (Barber 2004, Walker et al. 2011, Carballal et al. 2015), the etiology of disseminated neoplasia in $M$. arenaria is now well understood to involve transmission of a clonal lineage of neoplastic cells from one clam to another (Metzger et al. 2015, Mateo et al. 2016). In moribund $M$. arenaria, neoplastic hemocytes exhibit high genomic copy number and high RNA ex- 
pression of the Steamer retrotransposon. Steamer is a long terminal repeat (LTR)-retrotransposon in the Mag family of Ty3/Gypsy elements, complete with a single open reading frame encoding gag and pol genes. Retrotransposons are present in genomic DNA and replicate through reverse transcription of an mRNA transcript into DNA, followed by integration into a new location within the genomic DNA of a cell. As they are notably lacking a retroviral env gene, they are not expected to be able to transfer from cell to cell, as retroviruses do. Similar retrotransposons have been identified in the genomes of 3 other bivalve species known to have transmissible neoplasias, one of which seems to cross the species boundary (Metzger et al. 2016).

To date, the Steamer retrotransposon itself is unique to $M$. arenaria. Here we examined legacy biodiversity collections and freshly acquired bivalve tissues for the presence of a Steamer signature in their genomes in a manner that might (1) better elucidate whether disseminated neoplasias are ecologically or phylogenetically determined and (2) shed light on the potential for horizontal spread and genomic modification by Steamerlike retrotransposons in the marine environment.

\section{MATERIALS AND METHODS}

Bivalve tissue samples were obtained from the American Museum of Natural History's Ambrose Monell Cryo Collection (AMCC), and included 22 species from the North Atlantic (see Table S1 in the Supplement at www.int-res.com/articles/suppl/d124 p165_supp.pdf). Fresh specimens of steamer softshelled clams Mya arenaria were collected in June 2015 from Lattingtown Harbor Beach, New York (NY). Fresh specimens of Atlantic razor clams Ensis directus from Maine were obtained from Citarella (New York, NY). Fresh specimens of Pacific razor clams Siliqua patula were collected from Taylor Shellfish Farms (Bow, Washington). Fresh specimens of quagga mussels Dreissena rostriformis were collected from the Hudson River (New York State Museum). Fresh specimens of zebra mussels D. polymorpha were collected from the Seneca River (Baldwinsville, NY). Ethanol-preserved tissue samples of truncate softshells Mya truncata from Nunavut, Canada, were provided by the Canadian Centre for DNA Barcoding (University of Guelph, Ontario).

DNA isolates from all frozen and fresh samples were obtained using the E.Z.N.A. ${ }^{\circledR}$ Mollusc DNA Kit (Omega Bio-tek). All DNA concentrations were quantified using a Qubit fluorometer. Successful isolation was also confirmed through gel electrophoresis.
Attempts to amplify Steamer retrotransposon sequences from bivalve genomic DNA employed 2 primer pairs designed to amplify pol fragments specific to this retrotransposon (Stmr2988F ACT CCA AGC CGT CAA GAG AA with Stmr3340R TGC TTT CTG GCA AAT GAC TG; and Stmr2765F GCA TAA AGC GCC AAA GAG AC also with Stmr3340R) using $15.5 \mu \mathrm{l}$ of water, $2.5 \mu \mathrm{l}$ of $10 \times$ PCR Gold Buffer (Thermo Fisher Scientific), $2.5 \mu \mathrm{l}$ of $25 \mathrm{mM} \mathrm{MgCl}_{2}$, $2 \mu \mathrm{l}$ of $10 \mathrm{mM}$ dNTPs, $0.5 \mu \mathrm{l}$ of each $10 \mu \mathrm{M}$ primer, $0.5 \mu \mathrm{l}$ AmpliTaq Gold ${ }^{\circledR}$ (Thermo Fisher Scientific), and finally $1 \mu \mathrm{l}$ of DNA isolate. Amplification proceeded by way of a preliminary $5 \mathrm{~min}$ at $94^{\circ} \mathrm{C}$ followed by 55 cycles of $94^{\circ} \mathrm{C}$ for $15 \mathrm{~s}, 53^{\circ} \mathrm{C}$ or $54^{\circ} \mathrm{C}$ for $25 \mathrm{~s}$, and $72^{\circ} \mathrm{C}$ for $45 \mathrm{~s}$. In addition, and in order to positively identify host species, the cytochrome $C$ oxidase I barcoding locus ( $\operatorname{cox} 1)$ was amplified with LCO and HCO primers of Folmer et al. (1994), using Ready2Go PCR beads (GE Healthcare Life Sciences), to which $1 \mu \mathrm{l}$ of DNA isolate was added, along with $0.5 \mu \mathrm{l}$ both of the $10 \mu \mathrm{M}$ forward and the $10 \mu \mathrm{M}$ reverse primers and $23 \mu \mathrm{l}$ of distilled deionized water.

PCR amplification products were purified with AMPure (Agencourt Bioscience). Samples were cyclesequenced in both directions on an Eppendorf Mastercycler using $1 \mu \mathrm{l}$ ABI Big Dye Terminator v.3.1 (Applied BioSystems), $1 \mu$ Big Dye Extender Buffer v.3.1 (Applied BioSystems), $1 \mu \mathrm{l}$ of $1 \mu \mathrm{M}$ primer (above), and 3 to $7 \mu \mathrm{l}$ of cleaned PCR template, depending on the concentration of PCR product estimated by eye on electrophoretic gels. Sequences were purified by ethanol precipitation and analyzed with an ABI PRISM 3730 sequencer. Sequences were edited and reconciled using CodonCode Aligner. Sequences were aligned with MUSCLE (Edgar 2004), and alignments were distinguished by parsimony analysis using Mesquite (Maddison \& Maddison 2015) and confirmed via BLAST (Altschul et al. 1990) to the nr database at NCBI.

\section{RESULTS}

Amplification products were obtained from primers Stmr2988F and Stmr3340R for all Mya arenaria samples, for all samples of Ensis directus (including those from AMCC), and from 1 of 2 Macoma balthica in AMCC. The remainder of the sampled bivalve taxa from AMCC, as well as specimens of Siliqua patula, Mya truncata, and the 2 Dreissena species yielded no product for Steamer, although all yielded cox1 amplification products for the Folmer et al. (1994) primers, confirming viability of the DNA isolates. 
Output from BLAST querying each product from primers Stmr2988F and Stmr3340R to the nr database at NCBI returned high scoring matches only to the canonical Steamer retrotransposon sequence KF319019 (Arriagada et al. 2014). Pairwise alignments from BLAST, and multiple sequence alignment (see Fig. S1 in the Supplement), revealed 100\% sequence identity for amplified sequence products from all 10 specimens of $M$. arenaria with the canonical retrotransposon sequence KF319019, while revealing nucleotide variation and sequence length variation for amplicons obtained from all other taxa. Parsimony analysis of the aligned data revealed that all isolates grouped by taxon, and that the frozen specimens of $E$. directus and $M$. balthica possessed the most divergent sequences (Fig. 1). All sequences from $M$. arenaria were distinct from all other sequences obtained by the presence of a silent transitional point mutation (G2958 in M. arenaria; A2958 in all others). The sequence obtained from $M$. balthica included 2 transitions and 2 transversions compared to all other taxa. Nucleotide variation was observed among E. directus samples at 22 nucleotide positions, 10 of which were variable within a single individual (evidenced by equal chromatogram heights for 2 nucleotides in forward and reverse strands for $E$. directus sample numbers $8 \mathrm{R}, 3 \mathrm{R}, 13 \mathrm{~F}, 5 \mathrm{R}$, and 9R).

In addition to nucleotide site variation, alignment of the retrotransposon sequences (Fig. S1) revealed a homozygous shortened length variant for 2 specimens of E. directus. Relative to all other isolates, these 2 sequences were missing a region 109 nucleotides long. The 5' region flanking the missing region comprised nucleotides (...ag AAA ACA aca) that were complementary to the 3 ' flanking region (gt gtg TGT TTT gg...), and internally, 62 of 109 nucleotides were self-complimentary as an inverted doublet.

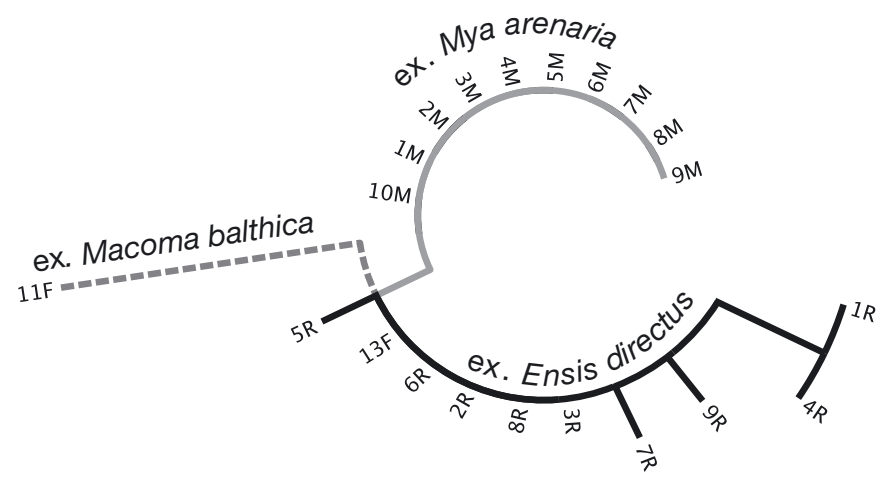

Fig. 1. Parsimony minimum spanning tree of Steamer retrotransposons isolates (also see the Supplement at www.intres.com/articles/suppl/d124p165_supp.pdf) obtained from surveyed bivalves. Branch lengths are proportional to the amount of change

\section{DISCUSSION}

Examination of a variety of bivalves demonstrates that the Steamer retrotransposon, which is known to be present in high copy numbers and is highly expressed in disseminated hemic neoplasia in Mya arenaria (Arriagada et al. 2014, Metzger et al. 2015, 2016), is also present in the genome of other relatively phylogenetically unrelated bivalves including Ensis directus and Macoma balthica. Furthermore, that Steamer is absent from Mya truncata (closely related to, but geographically isolated from, $M$. arenaria), and from Siliqua patula (closely related to, but geographically isolated from, E. directus) suggests that the distribution of this retrotransposon is not due to ancient common ancestry, but rather due to more recent crossspecies horizontal transmission. Despite their phylogenetic relatedness to retroviruses, retrotransposons do not normally move from cell to cell or species to species. The finding of sequences of nearly identical retrotransposons in 3 species suggests that horizontal transmission of the Steamer retrotransposon has occurred multiple times relatively recently. That the genera Mya, Ensis, and Macoma are representative of distinct and distantly related bivalve families (Myidae, Pharidae, and Tellinidae, respectively) suggests that phylogenetic constraints present little, if any, barrier to the spread of the Steamer retrotransposon. Notably, all 3 species now found to genomically harbor Steamer are infaunal filter-feeding bivalves with closely matched ecological and habitat distributions.

Horizontal transmission of transposons is rare (Schaack et al. 2010). Other comparatively rare transmissible cancers include devil facial tumor disease (DFTD), transmitted by bite among Tasmanian devils Sarcophilus harrisii (Pearse \& Swift 2006), and canine transmissible venereal tumor (CTVT) in dogs (Murgia et al. 2006); the proliferative cells of each downregulate expression of MHC class-I and class-II antigens allowing escape from immune detection (Rebbeck et al. 2009, Siddle \& Kaufman 2013). Other than what is implied for these disseminated neoplasia of bivalves, the only other known cross-species transmission of cancerous cells concerns the establishment of a tapeworm malignancy in the lungs of a highly immunocompromised patient (Muehlenbachs et al. 2015). Mechanisms similar to DFTD and CVTV may be at play in bivalves insofar as the putative infective cells are hemocytes responsible for non-self recognition via agglutination and aggregation factors (Moreira et al. 2012).

It is evident that there is markedly greater genetic diversity for Steamer among E. directus specimens 
(Fig. 1 and see Fig. S1), which is manifest in terms of length variation, as well as nucleotide polymorphism both among and within individual genomes of this species of razor clam. In comparison to the homogeneity of Steamer sequences from $M$. arenaria, this level of variation across coincident geographic ranges for soft-shell clams and Atlantic razor clams is consistent with $E$. directus as the ancestral source for what would appear to be a very recent horizontal transmission event to $M$. arenaria. The consequences of the introduction of a retrotransposon such as Steamer to the genomes of naïve organisms are unknown, but amplification of a retrotransposon does cause genomic changes which have the potential to lead to oncogenesis or other pathogenic outcomes. The massive amplification of Steamer in the transmissible neoplastic cell lineage in $M$. arenaria does suggest that their activity may be involved in oncogenesis. Whether M. balthica of the North Sea also are recently exposed by virtue of geographically and ecologically coincident invasive populations of $E$. directus should become evident with broader sampling of the Baltic clam.

The invasive Atlantic razor clam E. directus is now well established in the North Sea, where it is outcompeting the endemic razor clam, E. ensis (see Raybaud et al. 2015). In addition to its presence in $M$. arenaria in the northwest Atlantic, here we have shown the presence of Steamer in the North Sea invasive E. directus and in the North Sea endemic M. balthica. The presence or absence of this retrotransposon in the genome of $E$. ensis, and other mud-dwelling bivalves, deserves scrutiny, particularly as the distribution of $E$. directus suggests near-term expansion into the Adriatic (Raybaud et al. 2015).

Acknowledgements. We thank the staffs of the Ambrose Monell Cryo Collection and the Canadian Centre for DNA Barcoding for providing tissues from their collections. We thank Laura Whitman, James Danziger, and Tom Danziger for their assistance in collection of specimens from Lattingtown Harbor; and Lily Berniker, Rebecca Hersch, Na'ta'ne Miles, and Michael Tessler for their laboratory camaraderie and for reviews of early drafts of this manuscript. This research was supported by an REU Site grant from the Division of Biological Infrastructure of the National Science Foundation.

\section{LITERATURE CITED}

Altschul SF, Gish W, Miller W, Myers EW, Lipman DJ (1990) Basic local alignment search tool. J Mol Biol 215:403-410 Arriagada G, Metzger MJ, Muttray AF, Sherry J and others (2014) Activation of transcription and retrotransposition of a novel retroelement, Steamer, in neoplastic hemo- cytes of the mollusk Mya arenaria. Proc Natl Acad Sci USA 111:14175-14180

Barber BJ (2004) Neoplastic diseases of commercially important marine bivalves. Aquat Living Resour 17:449-466

* Carballal MJ, Barber BJ, Iglesias D, Villalba A (2015) Neoplastic diseases of marine bivalves. J Invertebr Pathol 131:83-106

Christensen DJ, Farley CA, Kern FG (1974) Epizootic neoplasms in the clam Macoma balthica (L.) from Chesapeake Bay. J Natl Cancer Inst 52:1739-1749

Edgar RC (2004) MUSCLE: multiple sequence alignment with high accuracy and high throughput. Nucleic Acids Res 32:1792-1797

Farley CA (1969) Probable neoplastic disease of the hematopoietic system in oysters, Crassostrea virginica and Crassostrea gigas. Natl Cancer Inst Monogr 31:541-555

Folmer O, Black M, Hoeh W, Lutz R, Vrijenhoek R (1994) DNA primers for amplification of mitochondrial cytochrome c oxidase subunit I from diverse metazoan invertebrates. Mol Mar Biol Biotechnol 3:294-299

* Maddison WP, Maddison DR (2015) Mesquite: a modular system for evolutionary analysis. Version 3.04. http:// mesquiteproject.org

Mateo DR, MacCallum GS, Davidson J (2016) Field and laboratory transmission studies of haemic neoplasia in the soft-shell clam, Mya arenaria, from Atlantic Canada. J Fish Dis 39:913-927

*Metzger MJ, Reinisch C, Sherry J, Goff SP (2015) Horizontal transmission of clonal cancer cells causes leukemia in soft-shell clams. Cell 161:255-263

Metzger MJ, Villalba A, Carballal MJ, Iglesias D and others (2016) Widespread transmission of independent cancer lineages within multiple bivalve species. Nature 534: 705-709

Moreira R, Balseiro P, Planas JV, Fuste B, Beltran S, Novoa B, Figueras A (2012) Transcriptomics of in vitro immunestimulated hemocytes from the Manila clam Ruditapes philippinarum using high-throughput sequencing. PLOS ONE 7:e35009

Muehlenbachs A, Bhatnagar J, Agudelo CA, Hidron A and others (2015) Malignant transformation of Hymenolepis nana in a human host. N Engl J Med 373:1845-1852

Murgia C, Pritchard JK, Kim SY, Fassati A, Weiss RA (2006) Clonal origin and evolution of a transmissible cancer. Cell 126:477-487

* Pearse AM, Swift K (2006) Allograft theory: transmission of devil facial-tumour disease. Nature 439:549

Pekkarinen M (1993) Reproduction and condition of unionid mussels in the Vantaa River, South Finland. Arch Hydrobiol 125:357-375

* Raybaud V, Beaugrand G, Dewarumez JM, Luczak C (2015) Climate-induced range shifts of the American jackknife clam Ensis directus in Europe. Biol Invasions 17:725-741

Rebbeck CA, Thomas R, Breen M, Leroi AM, Burt A (2009) Origin and evolution of a transmissible cancer. Evolution 63:2340-2349

Schaack S, Gilbert C, Feschotte C (2010) Promiscuous DNA: horizontal transfer of transposable elements and why it matters for eukaryotic evolution. Trends Ecol Evol 25: $537-546$

Siddle HV, Kaufman J (2013) A tale of two tumours: comparison of the immune escape strategies of contagious cancers. Mol Immunol 55:190-193

* Thiriot-Quiévreux C, Wolowicz M (1996) Karyotypes of Cerastoderma glaucum (Bivalvia) from Baltic and Mediterranean populations. Hydrobiologia 324:149-155

Walker CW, Van Beneden RJ, Muttray AF, Böttger SA, Kelley ML, Tucker AE, Thomas WK (2011) p53 superfamily proteins in marine bivalve cancer and stress biology. Adv Mar Biol 59:1-36 